\title{
Livelihood and Conservation Aspects of Non-wood Forest Product Collection in the Shaxi Valley, Southwest China ${ }^{1}$
}

\author{
Franz K. Huber ${ }^{2}$, Robert Ineichen ${ }^{3}$, Yongping Yang ${ }^{4}$, \\ and Caroline S. Weckerle*,3 \\ ${ }^{2}$ Society, Environment and Culture, Institute for Environmental Decisions, ETH Zürich, \\ Sonneggstrasse 33, 8092, Zürich, Switzerland; \\ ${ }^{3}$ Institute of Systematic Botany, University of Zürich, Zollikerstrasse 107, 8008, Zürich, Switzerland; \\ ${ }^{4}$ Kunming Institute of Botany, Chinese Academy of Sciences, Heilongtan, 650204, Kunming, \\ People's Republic of China \\ *Corresponding author; e-mail: weckerle@ethnobot.ch
}

\begin{abstract}
Livelihood and Conservation Aspects of Non-wood Forest Product Collection in the Shaxi Valley, Southwest China. The Shaxi Valley in Yunnan Province, P.R. China, is inhabited by Tibeto-Burman ethnic groups. We found a clear dichotomy between household strategies in the valley bottom and the mountain areas, with significantly lower household income in the mountains. The majority Bai people live predominantly in the fertile valley floor and cultivate rice, keep livestock, and commonly pursue off-farm work. Other ethnic groups live in more remote mountainous areas of the Shaxi Valley, where the collection of non-wood forest products, especially wild mushrooms, plays an important role in securing livelihoods. However, only households in the valley's central villages engage in the profitable non-wood forest product trade. Mushroom populations appear to be less vulnerable to commercial harvest than the rapidly declining wild medicinal plant populations. Due to this decline, local farmers have gained interest in cultivating medicinal plants, but only if risks are low and if financial and technical support is provided. Encouraging the cultivation of medicinal plants appears to be an appropriate means of sustainable community development.
\end{abstract}

中国西南地区沙溪流域的非木材林产品采集与生计和保护的关系. 沙溪流域位于中国西南 地区的云南省剑川县南部，居住有白、汉、粼、僳傈、纳西等多个藏一缅语系的少数民族。 我们发现: 在同一流域内, 山区农户的收入远不及坝区高, 两地的家庭生计策略大相径庭; 流域的主体民族白族居住在平坦而肥沃的坝区，以种植水稻、发展畜牧业以及寻找一些非 农收入作为生计发展策略，而居住在边远山区的其他一些少数民族，多以采集和销售非木 材林副产品, 特别是菌类以维系生计, 但从事非木材林副产品经销的人主要是来自坝区中 心村寨村民。研究还发现: 由于商业化采集, 当地的野生药用植物资源锐减, 而菌类资源受 威胁程度较小; 如果风险不大, 资金和技术有保障, 当地农户对种植药材表现出浓厚的兴 趣, 因此鼓励药材种植应是当地实现可持续发展的有效途径。

Key Words: Bai, ethnobotany, non-timber forest products (NTFP), Shaxi, Southwest China, Yunnan.

关键词：中国西南地区, 云南, 沙溪, 白族, 民族植物学, 非木材林产品

\footnotetext{
${ }^{1}$ Received 7 August 2009; accepted 25 June 2010; published online 15 July 2010.
} 


\section{Introduction}

\section{Non-Wood Forest Products}

Non-wood forest products (NWFPs) are valuable resources for rural livelihoods worldwide, both for subsistence and cash income (Neumann and Hirsch 2000). While some of them are important export commodities, such as bamboo, essential oils, honey, mushrooms, or plant parts for pharmaceutical products, others provide raw materials for further processing and create employment opportunities at a local level (FAO 1995). We use the term non-wood forest products for "... products consist [ing] of goods of biological origin other than wood, derived from forests, other wooded land and trees outside forests" (FAO 1999).

Since the market-oriented reforms of the early 1980s, policies in Southwest China have fostered interest in NWFPs as local income sources (Winkler 2003). The Himalayan foothills of Southwest China are one of the world's biodiversity hotspots, characterized by an extraordinary diversity of vascular plants and fungi (Boufford and van Dijk 1999; Yang 2005), many of which are collected for local uses as well as commercial trade (Wang et al. 1995; Weckerle et al. 2006).

Following the disastrous flooding in 1998, logging was banned in the upper reaches of the Yangtze and Yellow River, and the subsequent loss of forestry jobs and decline in tax revenues renewed an interest in NWFP collection (Winkler 2003). Studies have investigated the impact of commercial NWFP collection and market patterns on local livelihoods and ecosystems in Southwest China: the two focal species were the culinary matsutake (Tricholoma matsutake [S. Ito $\&$ S. Imai] Singer) from mountain forests, exported mainly to the Japanese market, and the medicinal caterpillar fungus (Ophiocordyceps sinensis [Berk.] Sacc.) from alpine grasslands, which is used in Traditional Chinese Medicine (TCM). Both of these widely-distributed species are traded and exported on a large scale and provide substantial income to rural communities with access to these resources (Arora 2008; Weckerle et al. 2010; Winkler 2008; Yang et al. 2008). Many other products are collected and traded on a smaller, often local scale, including medicinal and food plants and mushrooms (e.g., Meng et al. 2006). Many studies express a general concern over the perceived or confirmed decrease of wild populations of medicinal plants in particular, due to overcollection and land use change (Buntaine et al. 2007; Xu and Wilkes 2004). However, empirical evidence on long-term effects is limited, as little is known about the biology of the organisms and responses of plant populations to commercial harvest (Belcher and Schreckenberg 2007; Larsen and Olsen 2007).

\section{Research Area}

This study was conducted in the Shaxi Valley, located at the southern edge of the Hengduan Mountains, within the Himalayan foothills of northwest Yunnan Province. The Hengduan Mountains are recognized by Conservation International as a biodiversity hotspot of Southwest China (e.g., Myers et al. 2000; Olson and Dinerstein 2002). Shaxi Township in Jianchuan County, Dali Prefecture, encompasses 288 square $\mathrm{km}$, at elevations between 2,100-3,100 m (Fig. 1). The rainy season lasts from June to September, with an annual rainfall of 740-790 mm (Morel and Forster 2002). One-third of the Shaxi Valley is flat valley bottom, which is covered mainly by paddy fields. Valley slopes support subtropical mixed pine and oak forest (Pinus yunnanensis Franch. and Quercus spp.), and remnants of subtropical evergreen broad-leaved forest (predominantly Fagaceae, Lauraceae, Magnoliaceae, and Theaceae species). Forests at the bottom of the hills show strong anthropogenic disturbance such as livestock grazing, logging, and removal of understory vegetation, causing widespread erosion.

The Shaxi Valley is mainly inhabited by Bai people, an ethnic group comprising nearly two million people in China, with a majority living in Yunnan Province. Linguistically, the relationship of the Bai with other ethnic groups is unclear, as their language has Chinese, Tibeto-Burman, and Tai or Mon-Khmer elements (as reviewed by Schmitt 2007). In 2005, the population of the Shaxi Valley comprised approximately 22,900 people, of which $85 \%$ were Bai. Other inhabitants include Han (11\%), Yi (2.5\%), and Lisu (1.5\%; Ineichen 2007). Bai and Han largely inhabit the fertile valley floor (Fig. 2), while the Yi and Lisu reside at higher altitudes, usually living in scattered settlements (Fig. 3). More than $96 \%$ of the inhabitants are small-scale farmers. In 2004, the annual per capita income was around CNY 1,170 (Chinese yuan), or about USD 141 (as of December 30, 2004; Ineichen 2007).

The Shaxi Valley was part of the "southern Silk Road," harboring an important market place at 


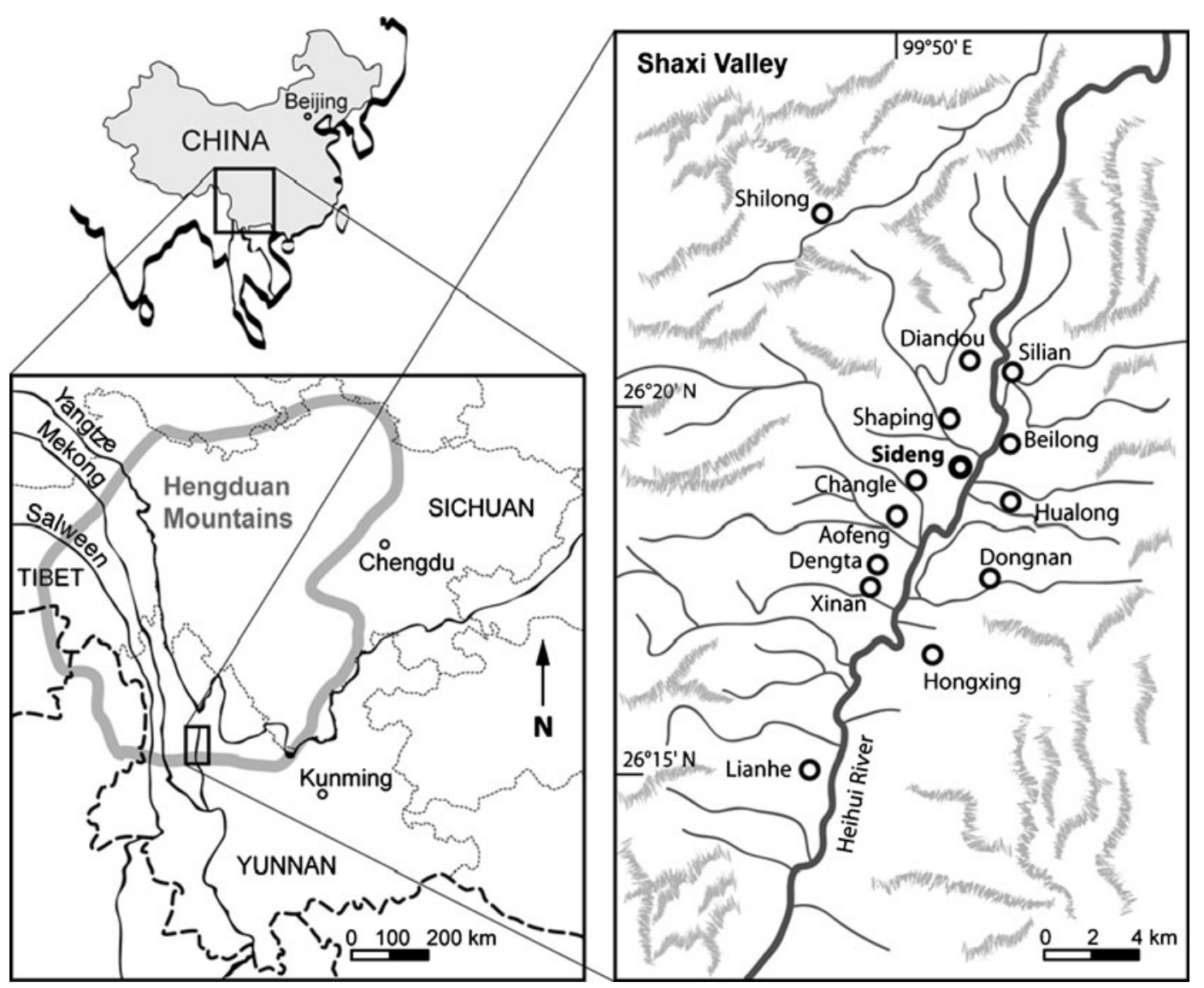

Fig. 1. Location of the study area in Southwest China and the 14 village groups in the Shaxi Valley.

Sideng, the Shaxi Valley's central village. In 2001, the World Monuments Fund placed Sideng on the list of the World's 100 Most Endangered Heritage Sites. Since then, the Shaxi Valley Rehabilitation Project (SRP), based on international collaboration between the Swiss Federal Institute of Technology Zürich (ETH) and the People's Government of Jianchuan County, has focused on sustainable development by generating a framework for ecological, economic, and social issues (Feiner et al. 2002). Main aims have been market place restoration, historic village preservation, sustainable valley development, ecological restoration and sanitation, and poverty alleviation.

In the context of this framework, the present study aims to provide a baseline for future analysis regarding the potential of cash crops and NWFP collection for poverty alleviation programs. We assessed subsistence and major income sources, the role of cultivated plants and wild-collected NWFPs for cash income, and the sustainability of wild collection of NWFPs. Based on this assessment, we address the question of whether the cultivation of medicinal plants could provide an additional income source for farmers in the area.

\section{Methods}

Fieldwork was conducted during three months from July to September 2005. Structured and semistructured interviews with a total of 72 interviewees were carried out in all 14 village groups of Shaxi (Fig. 1) as well as the county capital of Jianchuan. We interviewed village officials on population, economy, and agriculture issues (all villages groups except Shilong), 21 farmers on livelihood strategies and the role of NWFP collection, 29 farmers on medicinal plant knowledge and use, and nine middlemen and retailers of medicinal plants and mushrooms on commercial aspects of NWFP collection. Middlemen and retailers were chosen randomly for the 


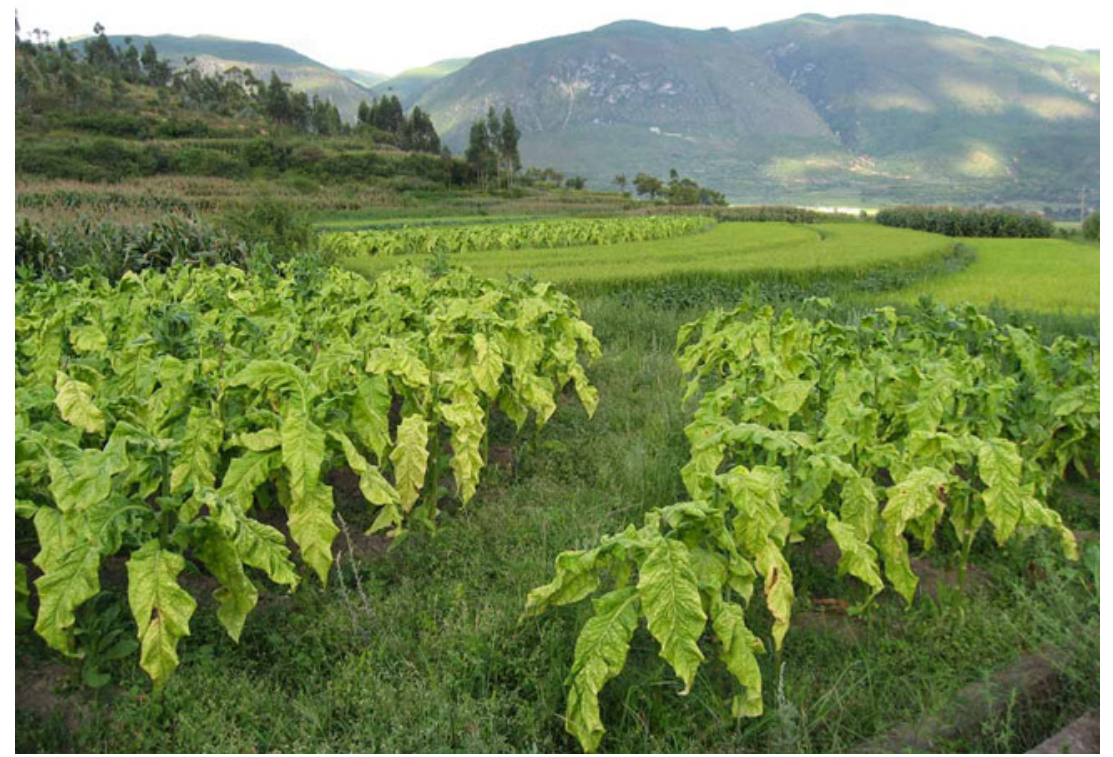

Fig. 2. Intensive agriculture in the valley bottom with tobacco in the foreground and rice paddy fields. Corn is grown in the rain-fed fields.

interviews based on listings provided by village group leaders. For farmers, the first of each village was generally chosen randomly and was then asked to name other contacts within the same village. All interviews were conducted in Chinese with the help of an interpreter. Walks in the area with key informants were conducted to trigger their recognition of useful plants. All information received was cross-checked with at least two additional interviewees.

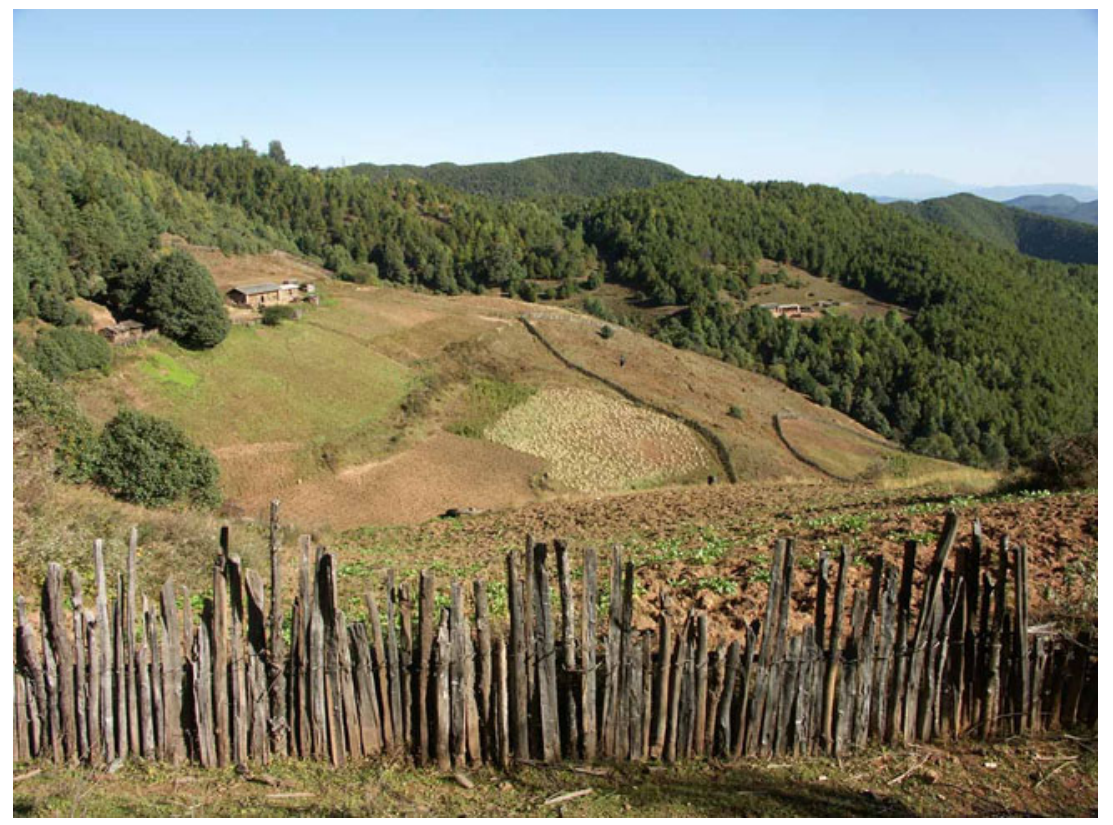

Fig. 3. Scattered houses on the hills. Potatoes, rapeseed, corn, and beans are cultivated in the fields. 
In the interviews, farmers were asked to provide data on household income and livelihood strategies for the year 2004 and 2005. When farmers were reporting income ranges, the mean value was used for calculations. For assessing livelihood strategies, farmers were asked to classify different income sources into four categories (not important; only as bartering means; additional income source; main income source), according to the importance for their households. Exchange rates at December 30, 2004, were CNY $1=\mathrm{USD}$ 0.1208 .

Independent Samples t-Test was used to test whether the means of income among villages are different, and Mann-Whitney $U$ tests were used to test for significantly different medians among pairwise comparisons of livelihood strategies between villages. Kendall's tau rank correlation coefficient was used to measure the association of amount of income with livelihood strategies. For statistical analysis, PASW Statistics 18 for Windows was used.

The plant and mushroom specimens were identified at the herbarium of the Kunming Institute of Botany, Chinese Academy of Sciences (KUN). Herbarium specimens are deposited at KUN and the herbarium of the University of Zurich and ETH (Z/ZT). Nomenclature follows the Flora of China (1994 to present), and the Collection of Chinese Herbal Drugs (QZHB 1983-1986).

The research was conducted according to the Convention on Biological Diversity, the Bonn guidelines (Secretariat of the Convention on Biological Diversity 2002), and the biodiversity rights of China, and informed consent was given by involved authorities and interviewees on the use and publication of the obtained results.

\section{Results \\ Subsistence and Major Income Sources IN SHAXI}

Table 1 provides an overview of cash income and main income sources of 21 different households in seven villages, and shows that while agriculture is the vital foundation for livelihoods, NWFP collection and wage labor account for most of the cash income in Shaxi. Subsistence farming meets the basic needs of the daily diet and also provides additional cash income. Agriculture is dominated by rice (Oryza sativa L.) and tobacco (Nicotiana tabacum L.) cultivation in the valley bottom, and corn (Zea mays L.), bean
(Phaseolus vulgaris L.), and potato (Solanum tuberosum L.) cultivation in the hills.

Table 2 gives an overview of the village-groups of Shaxi, their agricultural area, and main cultivated crops. All households in the valley bottom have paddy fields. After rice harvest, barley (Hordeum vulgare L.), wheat (Triticum aestivum L.), and rapeseed (Brassica napus L.) are grown in the fields. Toward the surrounding hills, rice paddies are replaced by corn and tobacco and sometimes chili (Capsicum spp.) or bugleweed (Lycopus lucidus Turcz. ex Benth.) plantations, depending on the area and the village-group. Orchards comprise mainly stone fruits, pomes, walnuts (Juglans regia L.), and chestnuts (Castanea mollissima Blume). Most of the walnut trees are recently planted as a result of the government's sloping land conversion program (SLCP; Chinese: tuigeng huanlin huancao zhengce), which discourages cultivation on slopes steeper than $25^{\circ}$ by compensating farmers for abandoning land, and instead planting trees and grass.

Above 2,400 m no rice is grown. Compared with the valley bottom, farmers at higher altitudes tend to have more arable land, which they cultivate extensively. However, due to the altitude, growing seasons are shorter and crop yields are lower. The main crops are potatoes, corn, buckwheat (Fagopyrum esculentum Moench), oat (Avena sativa L.), and beans, with potatoes being bartered against rice with the farmers of lower altitudes. Both in the hills and the valley bottom, corn, oat, and buckwheat are primarily used as fodder.

In general, incomes vary considerably between different families but are significantly lower among households in the hills (Independent Samples t-Test, $p=0.016$ ). Besides crop production for subsistence, different strategies for cash income generation are pursued and household strategies differ significantly between the hills and the valley. Important income sources in the hills are corn (Mann-Whitney $\mathrm{U}$ test, $p=0.039$ ), beans $(p<0.001)$, and mushroom collection $(p=0.001)$, while for the valley it is mainly rice $(p<0.001)$. No significant differences could be found for the importance of livestock or wage labor between the valley and the hills. Regarding livestock, the households in the lowland usually own between three and six pigs and some chickens. Some farmers keep cows, but rarely more than one per household. They are usually grazed in the surrounding forest. Very few households per village 


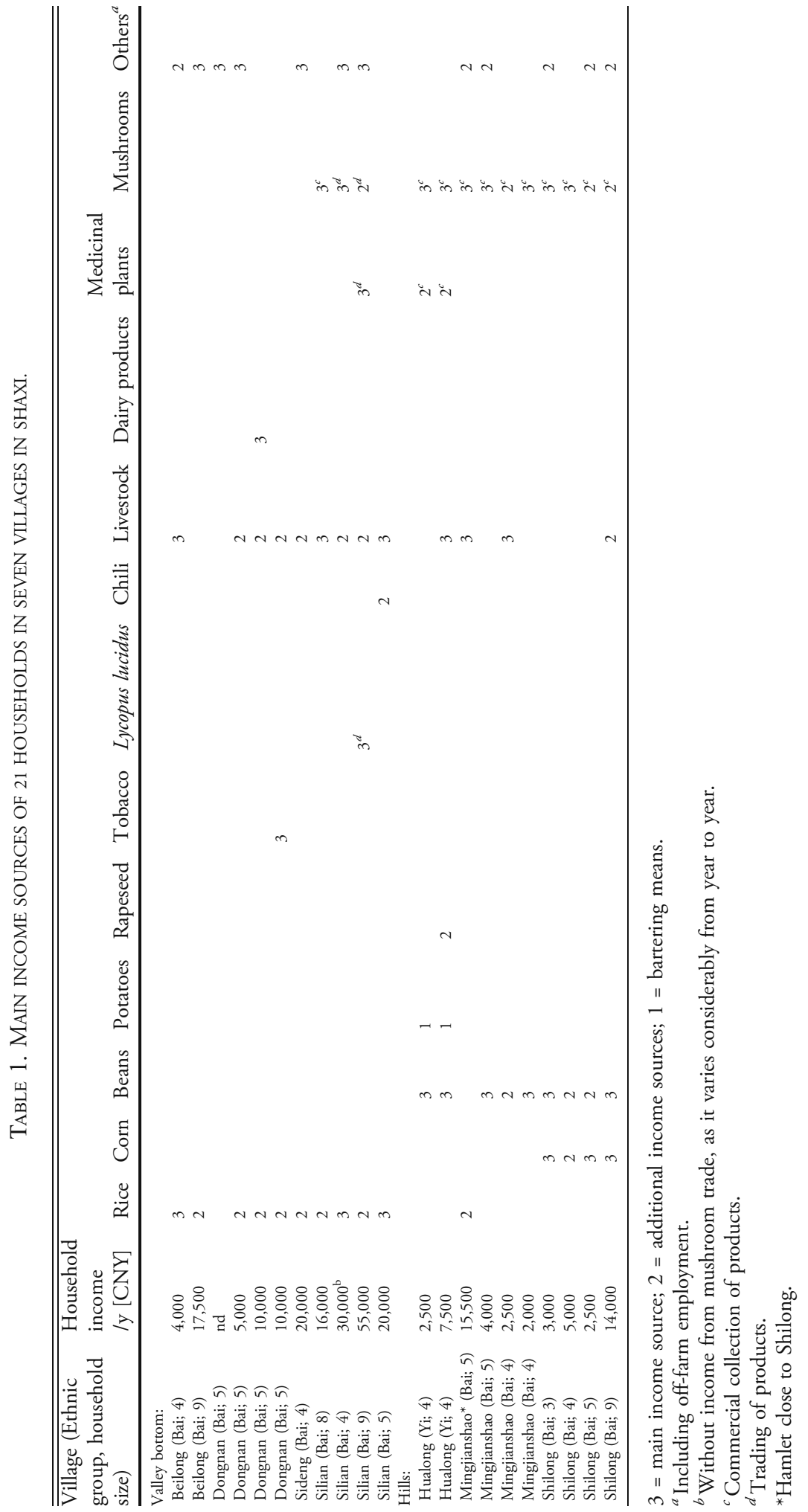




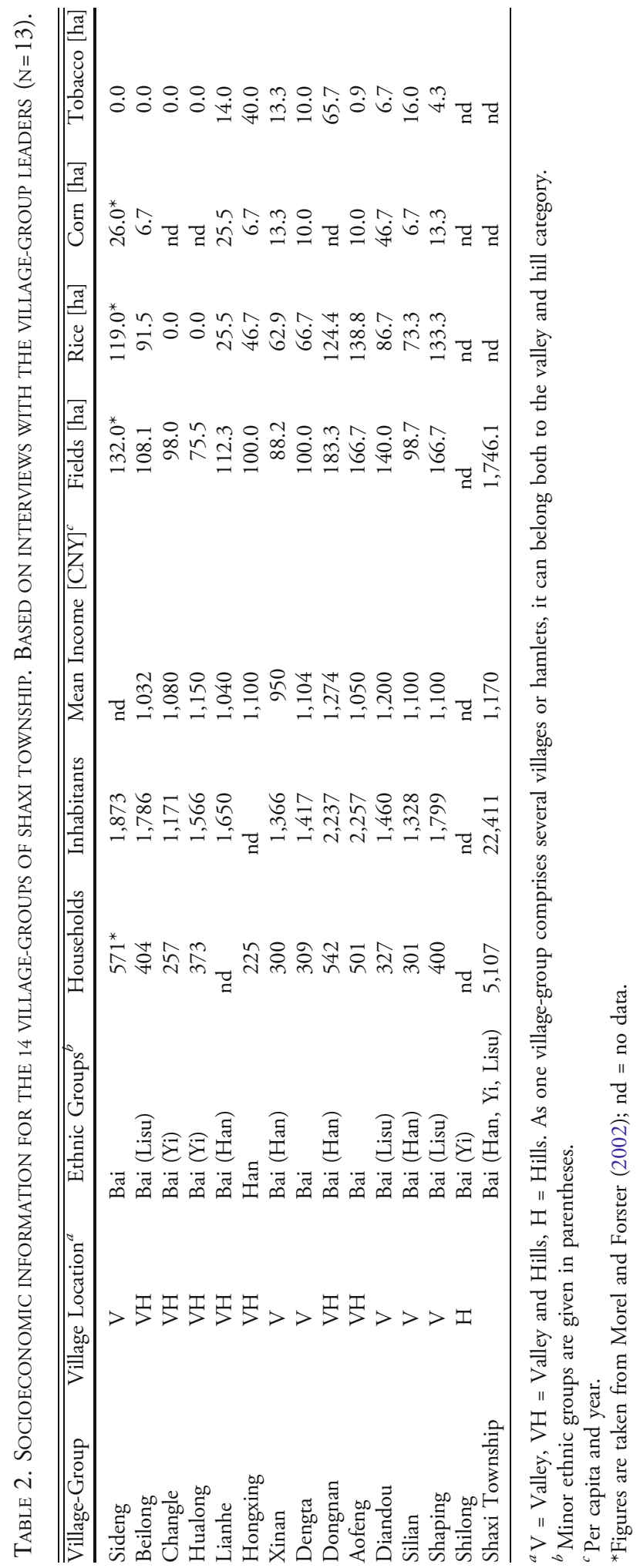


TABLE 3. HOUSEHOLD INCOME FROM DIFFERENT INCOME SOURCES PER YEAR AND PERCENTAGE OF HOUSEHOLDS PURSUING EACH STRATEGY.

\begin{tabular}{lrl}
\hline \hline Product & \% of Households $^{a}(\mathrm{n}=21)$ & Mean household income per year [CNY] \\
\hline Beans & $43 \%$ & $1,460 \pm 1,334(300-4,500)$ \\
Chili & $5 \%$ & 500 \\
Corn & $19 \%$ & $1,850 \pm 1,760(800-4,500)$ \\
Lycopus lucidus trade & $5 \%$ & 18,000 \\
Rice & $52 \%$ & $2,680 \pm 1,500(1,500-7,000)$ \\
Tobacco & $5 \%$ & 7,000 \\
Mushroom collection & $52 \%$ & $2,200 \pm 2,090(250-7,500)$ \\
Mushroom trade & $10 \%$ & $(1,000-45,000)$ \\
Medicinal plant collection & $10 \%$ & $350 \pm 210(200-500)$ \\
Medicinal plant trade & $5 \%$ & 7,500 \\
Dairy products & $5 \%$ & 6,000 \\
Livestock & $62 \%$ & $2,940 \pm 1,450(1,000-6,000)$ \\
Others & & $5,700 \pm 5,100(250-13,000)$ \\
\hline
\end{tabular}

${ }^{a}$ Twelve of the households do not produce enough food for subsistence and rely to different degrees on cash crops, NWFPs, and other sources for cash income.

${ }^{b}$ Values in parentheses represent range of minimal and maximal income recorded in the survey.

${ }^{c}$ Including occupation in the secondary and tertiary sector or public service, and employment of family members outside the valley.

now keep water buffalo, which were traditionally used for tillage and to homogenize and compact clay for brick production. In the hills, people keep pigs (usually between one and five per household), goats and chickens for meat, as well as horses and mules for transportation.

While the collection of NWFPs can substantially contribute to household income, it is obvious that trading of NWFPs can be especially rewarding (Table 3). Trading of NWFPs and Lycopus lucidus significantly correlates to a higher income (Kendall's tau $=0.444, p=0.023$ ), while the collection of NWFPs negatively correlates to income (Kendall's tau $=-0.407, p=0.029$ ). However, all interviewed dealers mentioned that dealing with medicinal plants or mushrooms is risky, as prices fluctuate strongly within and between seasons, occasionally resulting in losses.

\section{Important Non-Wood Forest Products (NWFPs)}

Interviews with farmers and medicinal plant specialists showed that a relatively broad knowledge of medicinal plants exists among the rural population of the Shaxi Valley (for a detailed description see Weckerle et al. 2009). Thirteen of 21 interviewed farmers mentioned that they use medicinal plants mainly for minor complaints, with three stating that they almost exclusively relied on medicinal plants for the treatment of diseases. Most, however, prefer pharmaceuticals which are readily available in shops, and it seems that it is mainly the poorer people, in remote places, who still rely heavily on medicinal plants.

Only two of the interviewed farmers, both belonging to the $\mathrm{Yi}$ and living in the hills, mentioned that they collect medicinal plants as a minor income source (Table 1); they mainly collect Bletilla striata (25-30 kg/y/p), Dipsacus asper (50$100 \mathrm{~kg} / \mathrm{y} / \mathrm{p}$ ), Erigeron breviscapus (ca. $50 \mathrm{~kg} / \mathrm{y} / \mathrm{p}$ ), and Paris polyphylla (ca. $30 \mathrm{~kg} / \mathrm{y} / \mathrm{p}$ ). All interviewees, both the collectors and traders, agreed that in the recent past populations of medicinal plants were much more abundant. Consequently, medicinal plants were collected by more people and over longer periods of time, and income from their collection played a much more important role for local livelihoods than now.

Table 4 gives an overview of the most important wild medicinal plants around Shaxi with amounts traded in the year 2005. Based on the information received in the interviews, it seems that only one person in Shaxi works on a regular basis as a medicinal plant dealer. The other two dealers interviewed trade on a year-byyear basis. All mentioned that the trade is only profitable with large amounts of plants, as small amounts are very difficult to sell. Usually, the dealers buy fresh plant material from the collec- 


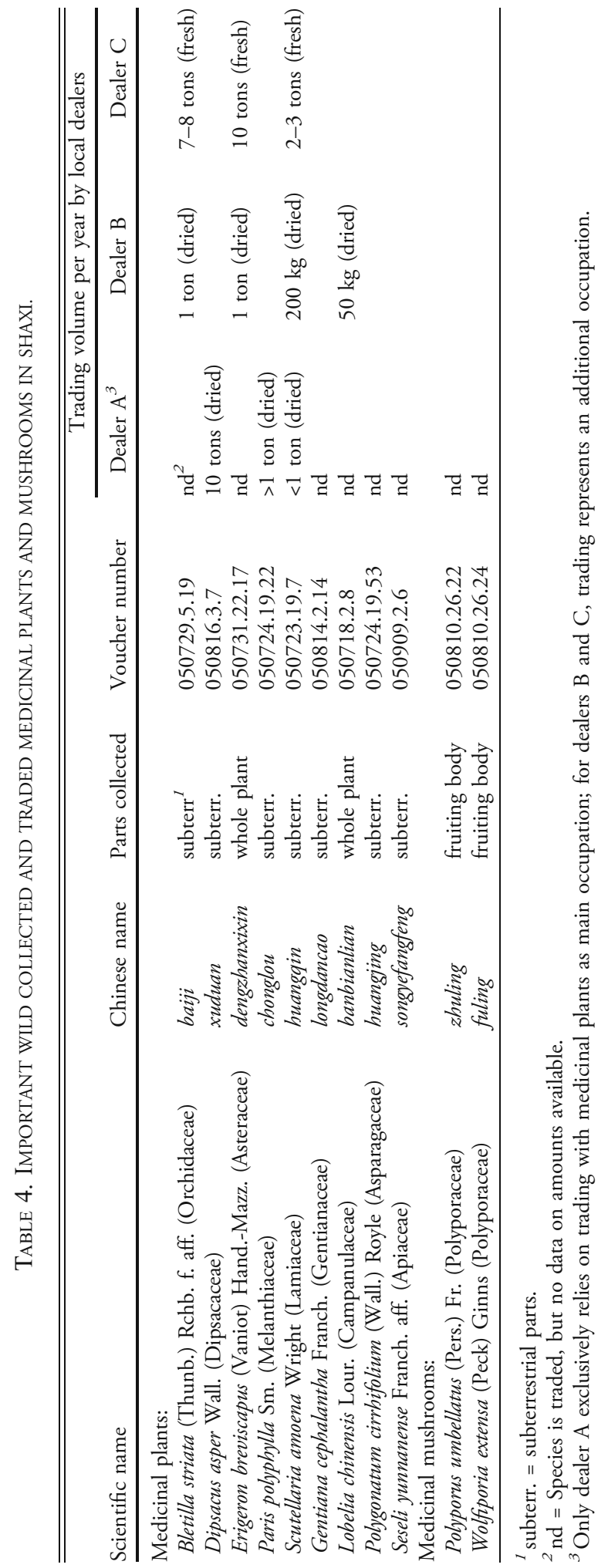


tors, dry it in their home, and finally sell it to middlemen from outside the valley. To buy plant material, they often visit adjacent valleys with more abundant supply and therefore lower prices. For Bletilla striata, the margin is around 15\%, whereas the margins of the other important medicinal plants are around $50 \%$.

Whereas most of the medicinal plants are collected for personal use and only some for trade, the reverse is true for mushrooms, which are widely collected and traded in Shaxi. Mushroom collection is predominantly practiced by the people living in the hills, while traders reside in the valley bottom. Table 5 provides an overview of the most frequently collected mushrooms, their prices in 2005, and an estimation of the traded amounts in Shaxi. The collection season lasts from June to September. The collectors start early in the morning to be the first to find the newlygrown fruiting bodies, and usually spend 3-5 hours per day in the forests. Most of the collectors concentrate on Boletus edulis (porcini) and Tricholoma matsutake (matsutake), as these are the most valuable species. Tricholoma matsutake is the most important income source for the majority of the collectors, who harvest between 5 and $50 \mathrm{~kg} /$ year. The local dealers separate the mushrooms into five different categories and pay CNY 20-200/kg, based on the quality. At the beginning and end of the season, up to CNY 500 can be gained for a single mushroom of superior quality.

Boletus edulis is quantitatively the most collected and traded mushroom in Shaxi. Local dealers buy the mushrooms from individual collectors and sell them to a factory, situated at the entrance of Sideng, where the mushrooms are processed. It is the largest factory in Shaxi, and between July and September, approximately 150 people are employed for a salary of CNY 700 per month. The mushrooms are cleaned, cut into pieces, and frozen at -20 to $-40^{\circ} \mathrm{C}$, before they are exported mainly to Italy and France. The factory opened in 2004 and its owner, who runs similar factories in other parts of Yunnan, explained that the quality of $B$. edulis in Shaxi is superior.

Other taxa are mainly collected for consumption at home or selling on a small scale. Among the farmers interviewed, 9 out of 21 primarily rely on mushroom collection for income generation and one on mushroom trade. The amounts collected per person and per year vary between 10 and $200 \mathrm{~kg}$, depending on the effort and skills of the collector and on weather conditions.
There are many middlemen, mushroom dealers, and people who do some small-scale mushroom processing in Shaxi and who also profit from the mushroom business. One of the middlemen buys matsutake from different villages, and then sells them in the county capital, earning up to CNY 20,000 per year. He estimates that wholesalers make up to CNY 100,000 in the same time. There are five wholesalers in Sideng who buy and process mushrooms before selling outside the valley. Conservative estimates for traded amounts in Shaxi, based on the information of middlemen and wholesalers, are 100 to $200 \mathrm{t}$ for Boletus edulis and 50 to $100 \mathrm{t}$ for Tricholoma matsutake and Hygrophorus russula (Table 5). These amounts exceed the traded amounts of medicinal plants several times over.

\section{Conservation Aspects}

Although market pressures have created an increasing interest in harvesting mushrooms in recent years, there has been no discernable decrease of harvestable amounts. In terms of trading, the main concern of the people in Shaxi relates to the fluctuating market prices of mushrooms, especially of the valuable Tricholoma matsutake, where a general decrease of the prices in recent years has been observed.

This sharply contrasts with the situation of the medicinal plants: all informants said that medicinal plant populations have decreased considerably over the last years and only few middlemen from outside the valley still come to Shaxi to buy them. One of the local dealers explained that harvests are too small now for a profitable business. Four years ago, a farmer was able to collect 15 to $20 \mathrm{~kg}$ of Erigeron breviscapus per day in Shaxi. Today, in the same time, he only finds $0.5-1 \mathrm{~kg}$. Local dealers are now buying plant material from more remote valleys, although harvest is decreasing in these places, too. The same dealer stated that between 2002 and 2005 the available daily harvest of E. breviscapus in Xiangtu, a valley neighboring Shaxi, decreased from 3,000 $\mathrm{kg}$ to $500 \mathrm{~kg}$ per day.

\section{Cultivation of Medicinal and Wild Food Plants}

Farmers both in the hills and the valley bottom are generally receptive to medicinal plant cultivation. Fifteen of the 21 farmers interviewed showed interest in the cultivation of medicinal 


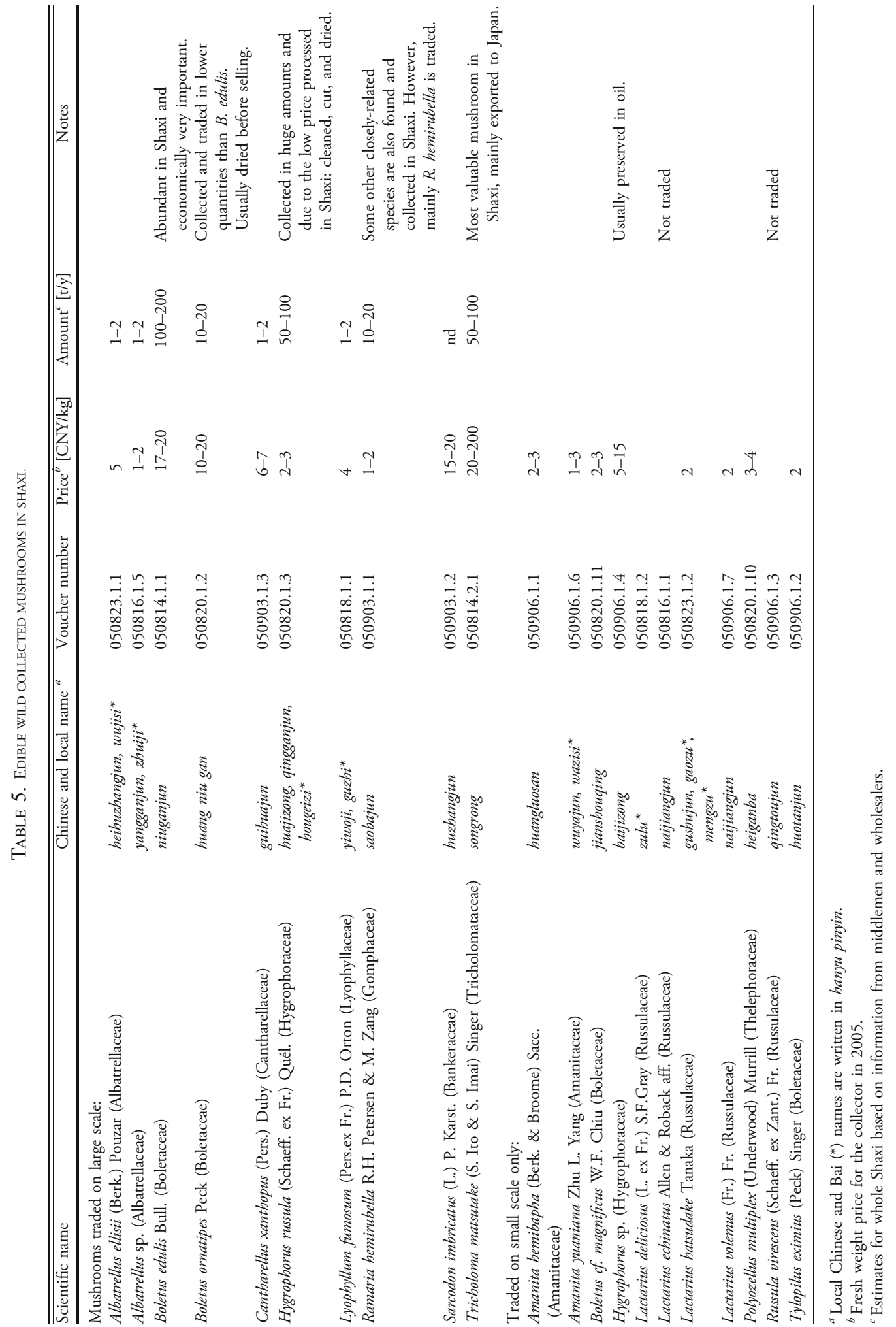


plants for income generation, but only if the risks of establishing a new crop are small. Five out of the 21 farmers have purchased seeds or have transplanted wild medicinal plants such as Erigeron breviscapus, Isatis indigotica Fortune ex Lindl., and Aconitum carmichaelii Debeaux, wild food plants like Lilium davidii Duch. and Lilium fargesii Franch., of which the flowers and bulbs are eaten, or orchids as ornamentals, and have grown them in their home gardens. The quantity usually remained limited. Two farmers lacked arable land, two were uncertain about medicinal plant cultivation, and two rejected the option.

In considering the options, the farmers formulate basic prerequisites for starting the cultivation of medicinal plants, such as fixed supply contracts, free distribution of seeds or seedlings, knowledge-building concerning cultivation and new technologies, as well as introductory courses led by experts.

Besides a lack of knowledge on the cultivation of medicinal plants, the main barrier to farmers committing to the establishment of a new product is the volatile market for medicinal plants. High prices one year might incentivize farmers to start cultivation, but a subsequent drop in price at harvest, or finding no purchaser at all, will discourage future enterprise. Traditional crop plants, on the other hand, guarantee a secure income, although profits are low.

\section{Discussion}

In Shaxi, the households in the valleys have a distinctly different livelihood strategy from those in the hill regions. In the flat and fertile valley bottom, households rely mainly on agricultural activities such as rice cultivation and livestock products as main income sources besides off-farm employment. Household income in the hills is significantly lower than in the valleys, and people mainly rely on crops other than rice (beans, corn, and also livestock) and on the collection of mushrooms as an important source of cash income. Among the collected mushrooms, Tricholoma matsutake ranks foremost in economic importance. It is mainly exported to Japan, where in 2006 average prices for imported matsutake were about USD 45/kg (Saito and Mitsumata 2008). Prices fluctuate strongly during the collection season, with peaks in May and June at the beginning of the main collecting season, as well as to a smaller degree at the end of the main collecting season in November and December, with people complaining that prices had generally declined in recent years. Amounts collected also vary considerably from year to year, mainly in response to weather conditions (Yang et al. 2008).

Although mushrooms are collected in Shaxi on a large scale, they do not show any signs of overharvesting. Collecting only affects the fruiting bodies, while the much larger underground mycorrhizal mycelia remains undisturbed. This coincides with findings from elsewhere, which did not show negative effects of intensive collection of mushrooms on wild populations (Arora 2008 and references therein).

In contrast, the abundance of medicinal plants in Shaxi has decreased dramatically in the past five years, in such a way that their collection has been abandoned by most former collectors. These findings are not surprising given the fact that of all major traded medicinal plants in the area, the subterrestrial parts, i.e., rhizomes, bulbs, or roots, or, in the case of Erigeron breviscapus, the whole plant, are collected, making the recovery of the populations difficult.

Non-wood forest product (NWFP) collection is market-driven, i.e., if the prices are high, NWFPs are collected regardless of potential impact on wild populations (Buntaine et al. 2007; $\mathrm{Xu}$ and Wilkes 2004). While this behavior so far has no negative impact on mushrooms, medicinal plant populations may be severely endangered. Studies on the impact of commercial harvest of perennial herbs on population level conclude that where the whole plant or the subterrestrial parts are collected, populations are very sensitive to harvesting; collection even at low rates leads to unsustainable use and a depletion of the resources (Law and Salick 2005 for China; Ghimire et al. 2005, 2008, and Larsen 2002 for Nepal; Charron and Gagnon 1991, Nantel et al. 1996, Nault and Gagnon 1993, and Rock et al. 2004 for North America). The majority of studies related to NWFP collection, however, rely on information from collectors and traders on reduced abundance and increased difficulty in finding the plants as an indicator of overcollection (e.g., Buntaine et al. 2007). For Southwest China, Xu and Wilkes (2004) state that several case studies showed a uniform correlation of overcollection to changes in market demand and prices, often associated with outsiders taking part in the exploitation of the local resources. Since our data for Shaxi is anecdotal, further research is needed to evaluate the effects of commercial harvest on medicinal plant populations in this area. 
Future conservation efforts need to take into account the socioeconomic importance NWFP collection has, especially for remote and poor households. This is of special importance in Southwest China, where conservation goals often have been addressed with large-scale and top-down policies such as the Sloping Land Conversion Program or the National Forest Protection Program, where neither socioeconomic nor ecological local characteristics are properly considered (McNally 2004; Weyerhaeuser et al. 2005; Xu et al. 2006, 2004; Yin and Yin 2010).

All agricultural and non-wood forest products (NWFPs) showed a potential to generate significant amounts of cash income. However, only households in the valley's central villages engage in the profitable trade of these products, where their more central location enables stakeholders to meet and thus gain more accurate information on market development. In addition, more diversified income streams, and larger financial scope, permit households to enter these riskier businesses.

The finding of this study, that households in the Shaxi Valley are able to employ a variety of different strategies not only to sustain livelihood but to generate significant cash income, indicates that this local socioeconomic system is reasonably resilient, and that it can even tolerate a significant decrease in one group of previously important NWFPs, namely medicinal plants.

However, the cultivation of medicinal plants could represent an opportunity to further diversify local livelihood strategies, as in the case of Lycopus lucidus. This wild vegetable has been known in Shaxi for a long time, but cultivation only started recently, 10 to 15 years ago, and today covers an area of around 30 hectares. Lycopus lucidus represents a successful cultivation experiment of a wild food plant on a small, individual basis, with subsequent acceptance on a broader scale. The dried rhizomes are sold to middlemen and retailers outside the valley. The crucial factor initiating the cultivation of $L$. lucidus is unknown, but the initiative came from farmers and not from the government, most probably due to a good market price.

Similarly, the cultivation of medicinal plants is generally seen as a possible means to conserve rare, endangered, or overexploited plants (e.g., FAO 1995; Rao et al. 2004; Schippmann et al. 2006; Xiao 1991; WHO, IUCN, and WWF 1993). Considering the large demand for medicinal plants for Traditional Chinese Medicine and the limited amount of arable land and forestry resources, locally-adapted silvo-medicinal agroforestry systems are seen as an efficient way to increase productivity, while at the same time contributing to the protection of ecosystems and livelihood security (Huang et al. 2002; Huang and Long 2007; Li 2001; Rao et al. 2004 for a review).

Community-based projects for the sustainable production of medicinal plants have been established in recent years throughout Southwest China (e.g., Pei et al. 2010). As most of the farmers show interest in medicinal plant cultivation, its community-wide promotion within the scope of the Shaxi Rehabilitation Project not only could improve individual farmers' livelihood security through diversification of household income but also comply with the aim of sustainable valley development by further strengthening the valley's economic stability.

\section{Conclusions}

The inhabitants of the Shaxi Valley continue to have a broad range of cash income sources, but with significantly different strategies in the hills and the valley bottom. They rely for their income mainly on agriculture and livestock, and, especially in the hills, on the collection of wild mushrooms. Despite high collection rates, mushrooms do not show any signs of depletion, in contrast to the reported decline in wild medicinal plant resources.

However, given the fluctuating and recent trend of decreasing prices of mushrooms, further diversification of livelihood strategies should be considered. The cultivation of medicinal plants in Southwest China has recently been a promising means to approach livelihood and conservation aspects concurrently.

Wild mushroom collection represents a sustainable, low-risk livelihood strategy for basic income mainly for upland farmers. The cultivation of medicinal plants requires some investment, but allows for growing high-value products and is therefore suitable for additional income in both low and upland areas. This further diversification can reduce the risks of loss of production of single resources and of the present price fluctuations. However, to be successfully implemented, there are a number of prerequisites, including the external logistical, technical, and financial support of participating farmers. Besides technical knowledge transfer from similar projects existing in Southwest China, a micro-credit scheme within the framework 
of the Shaxi Rehabilitation Project could be an initial start-up aid for a participatory development approach to securing farmers' livelihoods in the Shaxi Valley.

\section{Acknowledgments}

We thank all the people in Shaxi who made this study possible, especially the Ouyang family and Dr. Yang Wanlin. We are also very grateful to Chen Yuli for interpreting, Wang Xianghua for the identification of mushroom specimens, and, together with Rolf Rutishauser, Caroline FrancesKing and two anonymous reviewers for valuable comments on the manuscript. The study was financially supported by the Swiss National Science Foundation (PMPD33-118635) and the Swiss Academy of Sciences.

\section{Literature Cited}

Arora, D. 2008. The Houses that Matsutake Built. Economic Botany 62:278-290.

Belcher, B. and K. Schreckenberg. 2007. Commercialisation of Non-timber Forest Products: A Reality Check. Development Policy Review 25:355-377.

Boufford, D. E. and P. P. van Dijk. 1999. SouthCentral China. Pages 338-351 in R. A. Mittermeier, N. Myers, G. P. Robles, and C. G. Mittermeier, eds., Hotspots: Earth's Biologically Richest and Most Endangered Terrestrial Ecoregions. CEMEX, Mexico.

Buntaine, M. T., R. B. Mullen, and J. P. Lassoie. 2007. Human Use and Conservation Planning in Alpine Areas of Northwestern Yunnan, China. Environment, Development and Sustainability 9:305-324.

Charron, D. and D. Gagnon. 1991. The Demography of Northern Populations of Panax quinquefolium (American Ginseng). Journal of Ecology 79:431-445.

FAO. 1995. Non-wood Forest Products for Rural Income and Sustainable Forestry. Non-Wood Forest Products 7, Food and Agriculture Organization of the United Nations, Rome.

. 1999. FAO Forestry: Towards a Harmonized Definition of Non-wood Forest Products. Pages 63-64 in S. A. Dembner and A. Perlis, eds., Non-Wood Forest Products and Income Generation: Food and Agriculture Organization, Unasylva, Vol. 50, No. 198, Rome.

Feiner, J. P., S. W. Mi, and W. A. Schmid. 2002. Sustainable Rural Development Based on
Cultural Heritage: The Case of the Shaxi Valley Rehabilitation Project. DISP 151:7986.

Flora of China Editorial Committee, eds. 1994 to present. Flora of China. Science Press, Beijing, PR China, and Missouri Botanical Garden Press, St. Louis.

Ghimire, S. K., D. McKey, and Y. AumeeruddyThomas. 2005. Conservation of Himalayan Medicinal Plants: Harvesting Patterns and Ecology of Two Threatened Species, Nardostachys grandiflora DC. \& Neopicrorhiza scrophulariiflora (Pennell) Hong. Biological Conservation 124:463-475.

- O. Gimenez, R. Pradel, D. McKey, and Y. Aumeeruddy-Thomas. 2008. Demographic Variation and Population Viability in a Threatened Himalayan Medicinal and Aromatic Herb Nardostachys grandiflora: Matrix Modelling of Harvesting Effects in Two Contrasting Habitats. Journal of Applied Ecology 45:41-51.

Huang, J. and C. L. Long. 2007. Coptis teetaBased Agroforestry System and Its Conservational Potential: A Case Study from Northwest Yunnan. AMBIO 36:343-349.

Huang, W., O. Luukkanen, S. Johanson, V. Kaarakka, S. Räisänen, and H. Vihemäki. 2002. Agroforestry for Biodiversity Conservation of Nature Reserves: Functional Group Identification and Analysis. Agroforestry Systems 55:65-72.

Ineichen, R. 2007. Traditionen in Kultur: Medizinalpflanzen im Shaxi-Tal, Südwest-China. Master's thesis, Institute of Systematic Botany, University of Zurich, Switzerland.

Larsen, H. O. 2002. Commercial Medicinal Plant Extraction in the Hills of Nepal: Local Management System and Ecological Sustainability. Environmental Management 29: 88-101.

- and C. S. Olsen. 2007. Unsustainable Collection and Unfair Trade? Uncovering and Assessing Assumptions Regarding Central Himalayan Medicinal Plant Conservation. Biodiversity and Conservation 16:1679-1697. Law, W. and J. Salick. 2005. Human-Induced Dwarfing of Himalayan Snow Lotus, Saussurea laniceps (Asteraceae). Proceedings of the National Academy of Science 102:1021810220.

Li, W. H., ed. 2001. Agro-ecological Farming Systems in China. UNESCO, Paris. 
McNally, C. A. 2004. Sichuan: Driving Capitalist Development Westward. The China Quarterly 178:426-447.

Meng, Y., Y. P. Yang, and C. S. Weckerle. 2006. Conservation Status of Maianthemum Species in the Hengduan Mountains: A Case Study Analyzing the Impact of New Policies on Wild Collected Plant Species. Ethnobotany Research and Applications 4:167174.

Morel, A. and D. Forster. 2002. Sideng Mission Report. Environmental Sanitation Survey July-August 2002. SANDEC/EAWAG, Duebendorf, Switzerland.

Myers, N., R. A. Mittermeier, C. G. Mittermeier, G. A. B. da Fonseca, and J. Kent. 2000. Biodiversity Hotspots for Conservation Priorities. Nature 403:853-858.

Nantel, P., D. Gagnon, and A. Nault. 1996. Population Viability Analysis of American Ginseng and Wild Leek Harvested in Stochastic Environments. Conservation Biology 10:608-621.

Nault, A. and D. Gagnon. 1993. Ramet Demography of Allium triccocum, a Spring Ephemeral, Perennial Forest Herb. Journal of Ecology 81:101-119.

Neumann, R. P. and E. Hirsch. 2000. Commercialisation of Non-timber Forest Products: Review and Analysis of Research. Center for International Forestry Research, Bogor, Indonesia.

Olson, D. M. and E. Dinerstein. 2002. The Global 200: Priority Ecoregions for Global Conservation. Annals of the Missouri Botanical Garden 89:199-224.

Pei, S. J., A. C. Hamilton, L. X. Yang, H. Y. Huai, Z. W. Yang, F. Gao, and Q. X. Zhang. 2010. Conservation and development through medicinal plants: a case study from Ludian (Northwest Yunnan, China) and presentation of a general model. Biodiversity and Conservation. doi:10.1007/s10531-010-9862-5.

QZHB (Quanguo zhongcaoyao huibian bianxiezu; A Collection of Chinese Herbal Drugs Editorial Committee). 1983-1986. Quanguo Zhongcaoyao Huibian (A Collection of Chinese Herbal Drugs). Renmin weisheng chubanshe Beijingshi (People's Health Publisher, Beijing, PR China). (全国中草药汇编编写组。 1983 - 1986 。全国中草药汇编。人民卫 生出版社, 北京市。).

Rao, M. R., M. C. Palada, and B. N. Becker. 2004. Medicinal and Aromatic Plants in
Agroforestry Systems. Agroforestry Systems 61:107-122.

Rock, J. H., B. Beckage, and L. J. Gross. 2004. Population Recovery Following Differential Harvesting of Allium tricoccum Ait. in the Southern Appalachians. Biological Conservation 116:227-234.

Saito, H. and G. Mitsumata. 2008. Bidding Customs and Habitat Improvement for Matsutake (Tricholoma matsutake) in Japan. Economic Botany 62:257-268.

Schippmann, U., D. Leaman, and A. B. Cunningham. 2006. A Comparison of Cultivation and Wild Collection of Medicinal and Aromatic Plants under Sustainability Aspects. Pages 75-95 in R. J. Bogers, L. E. Craker, and D. Lange, eds., Medicinal and Aromatic Plants. Wageningen UR Frontis Series No. 17, Springer, Dordrecht.

Schmitt, J. H. 2007. Uprooted Referents: An Ethnography of Historical Consciousness among the Bai Nationality of the Dali Plain, Yunnan Province, the People's Republic of China. Ph.D. thesis, University of Virginia.

Secretariat of the Convention on Biological Diversity. 2002. Bonn Guidelines on Access to Genetic Resources and Fair and Equitable Sharing of the Benefits Arising out of Their Utilization. Secretariat of the Convention on Biological Diversity, Montreal.

Wang, X. P., Z. H. Yang, J. S. Horng, K. Iwatsuki, S. K. Yong, A. C. Hamilton, and S. D. Davis. 1995. Regional Overview: China and East Asia. Pages 145-197 in S. D. Davis, V. H. Heywood, and A. C. Hamilton, eds., Centers of Plant Diversity, Vol. 2. Information Press, Oxford.

Weckerle, C. S., F. K. Huber, Y. P. Yang, and W. B. Sun. 2006. Plant Knowledge of the Shuhi in the Hengduan Mountains, Southwest China. Economic Botany 60:3-23.

- , R. Ineichen, F. K. Huber, and Y. P. Yang. 2009. Mao's Heritage: Medicinal Plant Knowledge among the Bai in Shaxi, China, at a Crossroads between Distinct Local and Common Widespread Practice. Journal of Ethnopharmacology 123:213-228.

-, Y. P. Yang, F. K. Huber, and Q. H. Li. 2010. People, Money, and Protected Areas: The Collection of the Caterpillar Mushroom Ophiocordyceps sinensis in the Baima Xueshan Nature Reserve, Southwest China. Biodiversity and Conservation. doi:10.1007/s10531-0109867-0. 
Weyerhaeuser, H., A. Wilkes, and F. Kahrl. 2005. Local Impacts and Responses to Regional Forest Conservation and Rehabilitation Programs in China's Northwest Yunnan Province. Agricultural Systems 85:234-253.

WHO, IUCN, and WWF. 1993. Guidelines on the Conservation of Medicinal Plants. Gland and Geneva, Switzerland.

Winkler, D. 2003. Forest Use and Implications of the 1998 Logging Ban in the Tibetan Prefectures of Sichuan: Case Study on Forestry, Reforestation and NTFP in Litang County, Ganzi TAP, China. The Ecological Basis and Sustainable Management of Forest Resources. Informatore Botanico Italiano 35 (Sup.1):116-125. 2008. Yartsa Gunbu (Cordyceps sinensis) and the Fungal Commodification of Tibet's Rural Economy. Economic Botany 62:291305.

Xiao, P. G. 1991. The Chinese Approach to Medicinal Plants-Their Utilization and Conservation. Pages 305-313 in O. Akerele, V. H. Heywood, and H. Synge, eds., The Conservation of Medicinal Plants. Cambridge University Press, Cambridge.
Xu, J. C. and A. Wilkes. 2004. Biodiversity Impact Analysis in Northwest Yunnan, Southwest China. Biodiversity and Conservation 13:959-983.

Xu, Z. G., M. T. Bennett, R. Tao, and J. T. Xu. 2004. China's Sloping Land Conversion Programme Four Years on: Current Situation, Pending Issues. International Forestry Review 6:317-326.

Xu, J. T., R. S. Yin, Z. Li, and C. Liu. 2006. China's Ecological Rehabilitation: Unprecedented Efforts, Dramatic Impacts, and Requisite Policies. Ecological Economics 57:595-607.

Yang, Z. L. 2005. Diversity and Biogeography of Higher Fungi in China. Pages 35-62 in J. P. $\mathrm{Xu}$, ed., Evolutionary Genetics of Fungi. Horizon Bioscience, Norfolk.

Yang, X. F., J. He, C. Li, J. Z. Ma, Y. P. Yang, and J. C. Xu. 2008. Matsutake Trade in Yunnan Province, China: An Overview. Economic Botany 62:269-277.

Yin, R. S. and A. P. Yin. 2010. China's Primary Programs of Terrestrial Ecosystem Restoration: Initiation, Implementation, and Challenges. Environmental Management 45: 429-441. 